\title{
The Principal Strategy for Improving the Quality of Learning at an Integrated Islamic Elementary School
}

\section{Noviyana Rustam 1 , Murniati ${ }^{2}$, Niswanto 3}

DOI: 10.35445/alishlah.v13i1. 528

\begin{tabular}{l}
\hline Info Artikel \\
\hline Keywords: \\
Principal strategy \\
Learning quality \\
Elementary school
\end{tabular}

Kata kunci: Strategi kepala sekolah Mutu pembelajaran Sekolah Dasar

\begin{abstract}
This study aims to gather information about the principal's strategy and program for enhancing the quality of learning at SD IT Nurul Ishlah Banda Aceh. The researchers employed a descriptive method in conjunction with a qualitative analysis approach to address the study's difficulties and objectives. It relates to the consideration of data described in the context of the research site's reality. Interview guidelines and observation sheets were utilized as instruments. The Miles and Huberman model was used to analyze the data. The findings indicate that the principal's strategy for improving the quality of learning is based on planning, specifically on developing school programmes that adhere to eight educational standards and three quality standards established by the Integrated Islamic School Network (JSIT). It also needs to build the capacity of teachers and staff to improve the quality of learning, conduct coaching and self-development activities for students, and create an atmosphere of learning based on Ukhuwah Islamiah/family ties in Islam.
\end{abstract}

\begin{abstract}
Abstrak
Penelitian ini bertujuan untuk mengetahui mengenai strategi Kepala Sekolah dalam meningkatkan mutu pembelajaran SD IT Nurul Ishlah Banda Aceh, serta menjelaskan Program kepala sekolah dalam meningkatkan mutu pembelajaran SD IT Nurul Ishlah Banda Aceh. Berdasarkan masalah dan tujuan dalam penelitian ini, peneliti menggunakan metode deskriptif dengan analisis pendekatan kualitatif. Hal ini berkaitan dengan pertimbangan data yang digambarkan berupa realita yang terjadi pada tempat penelitian. Instrumen yang digunakan adalah pedoman wawancara dan lembar observasi. Analisis data menggunakan model model Miles dan Huberman. Hasil penelitian menunjukan bahwa strategi kepala sekolah dalam meningkatkan mutu pembelajaran berdasarkan pada perencanaan yang dilakukan kepala sekolah yaitu melakukan perencanaan program sekolah yang mengacu pada 8 standart pendidikan dan ditambah dengan tiga standar mutu Jaringan Sekolah Islam Terpadu (JSIT), meningkatkan kapasitas diri guru dan staf dalam rangka peningkatan mutu pembelajaran, melakukan kegiatan pembinaan dan pengembangan diri bagi peserta didik, suasana pembelajaran dilaksanakan berbasis ukhuwah islamiah/ikatan kekeluargaan dalam Islam.
\end{abstract}

\footnotetext{
${ }^{1}$ Universitas Syiah Kuala, Banda Aceh, Indonesia

Email : yananovi39@gmail.com

${ }^{2}$ Universitas Syiah Kuala, Banda Aceh, Indonesia

Email : murniati@unsyiah.ac.id

${ }^{3}$ Universitas Syiah Kuala, Banda Aceh, Indonesia

Email : niswanto@unsyiah.ac.id
} 


\section{INTRODUCTION}

Education is the acquisition of knowledge, skills, attitudes, and habits through the process of learning. According to Law No. 20 of 2003 on the National Education System, education is a deliberate and planned effort to create a learning environment and learning process in which students actively develop their potential for religious, spiritual strength, self-control, personality, intelligence, and noble character, as well as the necessary skills. sociedad, nación, y estado. School educational facilities are one of the venues for achieving these educational goals.

The principal is derived from two words: "Head" and "School." The term "head" can refer to an organization's or institution's chairman or leader. At the same time, the term "school" refers to an institution that serves as a location for receiving and imparting knowledge. In a nutshell, the principal is the leader of a school or other institution that serves as a venue for receiving and imparting knowledge. Wahjosumidjo (2005: 83) describes the principal as a functional teacher who is charged with the responsibility of leading a school where the teaching and learning process takes place or where teachers and students interact.

In a nutshell, a principal is a functional teacher tasked with leading a school where the teaching and learning process occurs or where teachers deliver lessons and students receive lessons interact. Thus, the principal might be seen as a leader in the educational unit, tasked with managing the educational unit he leads. Additionally, read the principal's functions and responsibilities. Gazali (2013:133) contends that schools are the second educational institution after the home, responsible for assisting the family environment in educating and teaching children and enhancing and broadening students' horizons and conduct. Schools are also agents of change in the future, as seen by the policies that have been established. In this scenario, as a leader in an educational institution, the principal must have a strategy for carrying out his responsibilities.

The principal's policy is anticipated to contribute to the establishment of a high-quality educational institution. The principal's quality significantly impacts the quality of school production in leading (Ishaq, 2016). As a result, the principal must be accountable for all school activities to enhance the school's quality. A primary strategy for enhancing the quality of learning in an educational institution is required to achieve school quality.

Several researchers have conducted a prior study on the primary strategy. Yasyakur (2019) studied leadership strategy (Nurwulan Iqra Islamic Center Foundation) in North Jakarta to improve teacher performance. Yasyakur (2019) demonstrated leadership in a democratic style, was not hasty in acting or making choices, and was always consultative. Mukhtar's (2015: 115) research on key tactics for enhancing teacher performance during the learning process demonstrates numerous approaches to increase the quality of learning in schools. However, they have not been as effective as anticipated. The researchers' and Mukhtar's problems are similar because the principal's technique is anticipated to increase school quality. Mamlukhah (2014) conducted study on school principals' strategies for enhancing Islamic religious education instruction quality. Additionally, Tanjong (2017) conducted the same research as researchers on the principal's strategy to improve the quality of learning. However, based on preliminary observations in Tanjong's research, the difference is that there are teachers who are not accountable for the implementation of assigned tasks, resulting in an ineffective learning process. It is necessary to understand the improvement programme of the educational institutions' quality of instruction. In comparison, studies have discovered that the principal's technique is tailored to educational institutions that have consistently enhanced the quality of learning.

Based on the benefits of the research discussed before, it is clear that the principal, in carrying out his or her responsibilities as an educational leader, needs particular tactics in order to accomplish the institution's goals. This research is critical in order to improve the quality of primary school learning. Elementary school is the most critical stage of education since it lays the groundwork for children's future success. A supportive educational atmosphere will go a long way toward laying the finest possible foundation for youngsters. 


\section{METHOD}

The researchers combined a descriptive method with a qualitative approach to analysis to address the study's difficulties and objectives. It is related to taking into account the data described in reality at the research site. According to Sugiyono (2016: 15), descriptive research aims to convey how existing problems should be managed using data. The purpose of this qualitative descriptive research was to elicit information and data regarding the principal's plan for enhancing the quality of learning at Integrated Islamic Elementary School Nurul Ishlah Banda Aceh. Because the data being examined is interactive, this research will begin by recording and summarising the data received from the data conclusions. It will continue until it becomes the research's conclusion. Purposive and snowball sampling is used to identify data sources.

According to Sugiyono (2018: 218-219), purposeful data collection is a technique that involves selecting data sources based on certain criteria. For example, the person claims to know the most about what we expect, making it easier for researchers to explore the object / social situation under study. Snowball sampling is a technique for selecting data sources that are initially small but grow in size over time. Researchers can increase the number of data sources until they reach a point where they are no longer adding fresh data. This is consistent with Sugiyono's (2016: 303) assertion that adding samples after the data is saturated does not add new data. The study takes place at Banda Aceh's Integrated Islamic Elementary School Nurul Ishlah, located on Jl. Peace, Pango Deah, Kec. Ulee Kareng. This research will take place between March and April 2021. The following activities are included: 1) administration of the research, 2) field observations and interviews, and 3) data processing and reporting. Numerous tools are utilized to assist with this research, including the following: The interview guide was used to guide interviews with pertinent sources for this research. The observation sheet is used to record data and information about the study.

The following data gathering strategies were employed in this study: interview, observation, and documentation. The analysis technique utilized in this study is a qualitative descriptive technique that entails gathering data in-depth via interviews, observation, and documentation and then evaluating the data until the report is prepared. In qualitative research, data analysis occurs both whiles and after the data collection procedure is complete.

\section{FINDINGS AND DISCUSSION}

\section{Principal Program in Improving the Quality of Learning}

The programme for improving the quality of learning begins with programme planning. Based on the study's findings, programmes have been planned and included in the school's curriculum guidebook. This book contains a wealth of information about improving the quality of learning in schools that adhere to national education standards and the Network Educational Islam Integrated, which was approved jointly during its preparation. In implementing learning based on national education standards and JSIT, research was undertaken on Ukhuwah Islamiah/family ties in Islam to ensure that all school citizens know their roles and responsibilities under the school's hallmark.

Typical school characteristics IT Fundamentals According to Nurul Ishlah's book guide, the school's curriculum is an integrated curriculum or integrated curriculum. It is a full-day school or a half-day school, daily with the Qur'an, Tahfidzul Qur'an, and Communicative Interventive. The communication with parents is done concurrently between schools and at home (including kids' worship at home) by stuffing the sheets Birrul Walidain.

Additionally, the school has been promoting and developing students' self-esteem. Selfdevelopment activities are classified into programmatic self-development activities (extracurricular) and non-programmatic self-development activities (habituation). Then, to increase the quality of learning, self-capacity development activities for teachers and staff are conducted, and the learning climate in this school is founded on Islamic Ukhuwah. According to Sulastri et al. (2017) research, the principal's leadership has a favourable and significant effect on school quality. As a result, quality assurance must be controlled that adheres to established standards and expectations. 


\section{Principal Strategy in Improving the Quality of Learning}

To enhance the quality of learning, observations and interviews with teachers reveal that the principal has made numerous efforts to enhance the quality of learning. The principal reveals that he is constantly looking for innovations, such as significant during the online learning period. Pandemic covid-19 is to continue developing and seeking guidance for the smooth operation of implementing learning activities and evaluating instructional time spent online. The documentation results indicate that there are guidelines or rubrics for evaluation used for online learning.

Guidelines for evaluation and guiding methods serve as the standard for implementing online and offline learning beyond the new normal. According to observations and interviews, the new normal's learning period has been divided into two groups; morning and afternoon. Each group of classes (three classes, namely class I, II, and III, can be referred to as a group first and classes IV, V, and VI, can be referred to as a group of two ) will exchange groups once a week to learn. The morning group began as usual at 8:00 a.m. and ended at noon, while the afternoon group began at 1:00 p.m. and ended at 4.00 p.m.

Additionally, to ensure the smooth operation of the learning programme and connection with parents, the school has implemented the usage of the WhatsApp application (WA) and the establishment of assignment for each class. It has a significant impact on how learning is carried out throughout the Covid-19 epidemic and new normal. Based on observations made during the student pick-up period, the school collaborates with the inter-class coordinator to call kids when their parents pick them up. The assignment is given via the Whatsapp application (WA) by instructors protesting the current duty. Thus, it is sufficient for parents to wait routinely for their children to be picked up. During learning exercises, the teacher connects with students' parents via the WA to ensure that the online learning process is successful. Seriously, all shapes of ease in school have been achieved via information technology long before the pandemic covid-19 struck to facilitate the learning process both at school and at home with their parents. It is in line with Thomas et al. research (2020) that explain the successful programs in other countries have involved co-teaching between parents, teachers, preservice teachers and a participatory approach to teaching practices.

Then there is a coaching activity for teachers and staff called Islamic Personal Development or Ruhiyah guidance, which involves coaching and evaluating attitudes and changes resulting from increasing school learning activities. Additionally, this activity is linked to an increase in memorizing the Qur'an with weekly memorizes. To memorizing, meeting activities are conducted once a month to assess the overall performance of the school's programme. According to the description above, the principal's strategies have affected the quality of learning.

\section{Constraints faced by the Principal in Improving the Quality of Learning}

The principal makes every effort to remove impediments to enhancing the quality of learning in schools. The principal's approach to overcoming barriers to improving the quality of learning is to engage with internal and external stakeholders, such as the business and industrial world and nongovernmental organizations and government agencies. It is in line with Bolivar's research (2006), who found that results from the research suggest that such constraints determine that school leadership practice is management and maintenance-oriented rather than change-oriented, thus casting doubts about the very model of school leadership. The principal does this to assist in funding school programmes that contribute to the overall quality of learning in schools. Then conduct training activities, comparative studies, workshops, seminars, and anything else connected to teacher and staff self-capacity building. This is consistent with the findings of Liskayani et al. (2018), who discovered that one of the principal's efforts to improve the quality of education in school is to remain in the location to which he is assigned. To socialize with the community surrounding the school about the critical nature of education for school-aged children, improve teachers and educators' qualifications, and improve the competence of students and graduates. 


\section{CONCLUSION}

The principal's strategy in improving the quality of learning is based on planning carried out by the principal, namely planning school programs that refer to 8 national education standards and three quality standards of the Integrated Islamic School Network (JSIT). Increasing the capacity of teachers and staff to improve the quality of learning, conducting coaching and self-development activities for students, and the learning atmosphere carried out based on Islamic brotherhood/kinship ties in Islam. In improving the quality of learning, the principal collaborates with internal and external parties, such as the Business and Industrial World ( DUDI ) and LSM and government agencies, and conducts training activities, comparative studies, workshops, seminars, self-capacity building for teachers and staff. This result of this study is hoped useful for other principal in improving the quality of the learning process. The result of the study can be referenced on making the educational policy for stakeholder of integrated Islamic elementary school that support teachers in developing their competence, providing supportive infrastructure, and organizing regular training.

\section{REFERENCES}

Bolívar, A., Moreno, J.M. (2006). Between Transaction and Transformation: The Role of School Principals as Education Leaders in Spain. $J$ Educ Change 7, 19-31. https://doi.org/10.1007/s10833-006-0010-7

Gazali, M. (2013). Optimalisasi Peran Lembaga Pendidikan untuk Mencerdaskan Bangsa. Jurnal AlTa'dib. Vol. 6, No. 1

Hendarman dan Rohanim. (2018). Kepala Sekolah Sebagai Manajer Teori dan Praktik. Bandung: PT Remaja Rosdakarya.

Ishaq. (2016). Kepemimpinan Kepala Sekolah Dalam Meningkatkan Kinerja Guru Pada SMA Negeri 4 WIRA Bangsa Meulaboh Dan SMA Negeri 3 Meulaboh. Jurnal Administrasi Pendidikan Pascasarjana Universitas Syiah Kuala. Vol. 4, No. 1.

Yasyakur, Moch. (2019). Strategi Kepala Sekolah dalam meningkatkan kinerja guru di SMA YANIIC (Yayasan Nurwulan Iqra Islamic Center) Jakarta Utara. Bina Manfaat Ilmu, Jurnal Pendidikan. Vol.2, No.5.

Liskayani, L., \& Sulastri, S. 2018. Principal Strategies in Rural Areas to Improve the Quality of Education and Character of School Residents. JMKSP (Journal of Management, Leadership and Educational Supervision), 3(1), 77-89

Mukhtar. (2015). Strategi Kepala Sekolah Dalam Meningkatkan Kinerja Guru Pada SMP Negeri Di Kecamatan Mesjid Raya Kabupaten Aceh Besar. Jurnal Magister Administrasi Pendidikan Universitas Syiah Kuala. Vol. 3, No. 3.

Mamlukhah. (2014). Strategi Kepala Sekolah Dalam Meningkatkan Mutu Pembelajaran Pendidikan Agama Islam Di MA Al Amiriyah Blokagung Tegalsari Banyuwangi. Jurnal Pendidikan, Komunikasi, dan Pemikiran Hukum Islam. Vol. VI, No. 1.

Rohmat. (2010). Kepemimpinan Pendidikan Konsep dan Aplikasi. Purwokerto: STAIN Press.

Syamsul, Herawati. (2017). Penerapan Kepemimpinan Kepala Sekolah Dalam Meningkatkan Kinerja Guru Pada Jenjang Sekolah Menengah Pertama (SMP). Jurnal Idaarah. Vol. 1, No. 2.

Sutarto. (2015). Manajemen Mutu Terpadu (MMT-TQM) Teori dan Penerapan di Lembaga Pendidikan. Yogyakarta: UNY Press.

Sugiyono. (2016). Metode Penelitian (Kuantitatif, Kualitatif dan R\&D). Bandung: Alfabeta.

Sugiono. (2014). Memahami Penelitian Kualitatif. Bandung: Alfabeta.

Sugiyono. (2018). Metode Penelitian (Kuantitatif, Kualitatif dan R\&D). Bandung: Alfabeta.

Sulastri, S., Nurkolis, N., \& Rasiman, R. 2017. Effect of Principal Leadership and Work Motivation on Primary School Quality in Jepara Regency. Journal of Education Management (JMP), 5(3), 346361.

Syamsul, Herawati. (2017). Penerapan Kepemimpinan Kepala Sekolah Dalam Meningkatkan Kinerja Guru Pada Jenjang Sekolah Menengah Pertama (SMP). Jurnal Idarah. Vol.1,No. 2. 
Tanjong, Putri. (2017). Strategi Kepala Sekolah Dalam Peningkatan Mutu Pembelajaran Di SMAN 1 Samalanga. Universitas Islam Negeri Ar-Raniry. Banda Aceh.

Torang, S. 2016. Organization \& Management (Behavior, Structure, Culture \& Organizational Change). Bandung: Alfabeta

Undang-Undang Nomor 20 tentang Sistem Pendidikan Nasional Tahun 2003. 2003. Jakarta: PT. Kloang Klede Putra Timur.

Widiyarti dan Suranto. (2019). Konsep Mutu dalam Manajemen Pendidikan Vokasi. Semarang: ALPRIN.

Yulmawati. (2016). Strategi Kepemimpinan Kepala Sekolah Dalam Meningkatkan Mutu Pendidikan SD Negeri 03 Sungayang. Jurnal Manajemen, Kepemimpinan, dan Supervisi Pendidikan. Vol. 1, No. 2.

Zaini, Muhammad dan Heri Fajri. (2020). Kompetensi Manajerial Kepala Sekolah Dalam Meningkatkan Mutu Pembelajaran Guru (Studi Kasus Pada SMA Negeri 2 Indra Jaya Kabupaten Pidie). Jurnal Real Riset. Vol. 2, No. 3.

Wahjosumidjo (2005). Kepemimpinan Kepala Sekolah, Tinjauan Teori dan. Permasalahannya. Jakarta: Raja Grafindo Persada. Veithzal Rivai. (2004). 